\title{
Different testers influence genetic correlational response in narrow-based maize population NSA15
}

\author{
Dušan Stanisavljević · Dragana Rajković · Bojan Mitrović · \\ Miroslav Zorić · Petar Čanak · Filip Franeta $\cdot$ Milan Mirosavljević
}

\begin{abstract}
Summary: The goal of this study was to determine correlations between grain yield and other morphological and agronomical traits in two groups of maize half-sib (HS) progenies. Progenies were obtained by crossing every S1 family with two unrelated inbred lines as testers, NS732 and NS27. Field trials with incomplete block design, with replicates within set were conducted in 2008 and 2009 at four locations. The following traits were observed: grain yield, ear length, kernel row number, kernel number per row, 1000-kernel weight, plant height, ear height, number of leaves above ear and grain moisture. Significant moderate strong negative correlation between grain yield and ear length was determined in HS1 progeny. High significant correlations occurred among plant and ear height in both HS and between plant height and number of leaves. Observed differences in levels of correlation imply significant influence of tester in each group on HS progeny.

Keywords: correlations, ears, genetic correlations, grain yield, half-sib progenies, height, maize
\end{abstract}

\section{Introduction}

The main objectives of maize breeding program are directed towards development of genotypes with increased yield potential, wide adaptation and high responses to agronomic inputs. Development of new maize genotypes requires appropriate selection of effective testers in order to correctly classify and discriminate potential of newly created inbred lines (Rissi \& Hallauer 1991). So far, different progeny types have been used to investigate correlations among starting breeding material. Half-sib progenies derived from crossings with inbred lines as testers are most often employed (Hallauer et al. 2010).

Information on phenotypic and genotypic variability is of high importance in maize breeding. Therefore, relationship among major agronomic and morphological traits, interrelation with yield is essential for successful maize selection. Complex traits, such as grain yield, show lower heritability due to numerous genetic and environmental factors that influence their expression. Apart from higher yield selection, parallel selection on two or more traits should be considered.

D. Stanisavljević* · D. Rajković - B. Mitrović · M. Zorić · P. Čanak F. Franeta $\cdot$ M. Mirosavljević

Institute of Field and Vegetable Crops, M. Gorkog 30, 21000 Novi Sad, Serbia

e-mail: dusan.stanisavljevic@ifvcns.ns.ac.rs
Genetic correlation represents amount of genetic or non-genetic relation between two or more traits. Moreover, if one trait changes during selection, other traits will change in amount that corresponds to their genetic correlation relationship. Main causes of genetic correlation among traits are pleiotropy and linkage disequilibrium. However, when genes are not linked, linkage disequilibrium has no significant effect on genetic correlation between traits in open pollinated population. Strong genetic correlation between traits and high heritability of secondary trait, are prerequisites for successful indirect selection. Hallauer and Miranda (1988) concluded that middle strong correlations occur among grain yield and plant height, ear length and kernel number per row. According to Alvi et al. (2003), strongest genetic correlations appear between grain yield on the one side, and ear length and kernel number per row on the other side.

Therefore, information about relations between traits, especially with grain yield is necessary. The objective of this research was to determine effect of different testers on genetic correlations among grain yield and other morphological and agronomical traits of two maize half-sib (HS) progenies.

Acknowledgements: This research was supported by the Serbian Ministry of Science, Project No. TR31073 Improving the production of maize and sorghum under stress. 


\section{Materials and Methods}

Population of narrow genetic base NSA15, FAO maturity group 700, was used in our study. First of all, two inbred lines NS15 (derived from combination of $25 \%$ South American material and $75 \%$ of adapted sources) and NS61 (Lancaster based) were crossed in 2005. Secondly, $F_{1}$ plants were selfed in winter generation $(2005 / 06)$ to obtain NSA15 bi-parental population. Later on, 300 plants were planted from $\mathrm{F}_{2}$ seed in 2006. One hundred plants experienced random selfing, from which 50 ears were chosen when harvesting. All of $50 \mathrm{~S}_{1}$ families were sawn in 2007 with ear to row method. Further, 15 randomly selected plants from each $S_{1}$ family were crossed with each genetically unrelated tester-inbred lines NS732 and NS27. NS732 (FAO mature group 500) belongs to ID (Iodent) heterotic group, while NS27 (FAO mature group 500) belongs to BSSS (Iowa Stiff Stalk Synthetic). Finally, two groups of half-sib progenies (HS), each with 40 genotypes, were formed so that every $S_{1}$ family was crossed with both testers.

HS progenies were evaluated in incomplete block design, with replicates within set (Cochran \& Cox 1957) in 2008 and 2009 at four locations: Rimski šančevi, Srbobran, Sremska Mitrovica and Kikinda. Due to extended drought, uneven germination and plant growth, trial from 2009 in Kikinda was excluded from statistical analysis. For each HS progeny there were independent trials with two sets in two replicates per set. There were four hybrids (standards) in every trial (two inbreds-testers $\mathrm{x}$ lines that formed population): st1 $=\mathrm{NS} 732 \times \mathrm{NS} 61$, st2=NS27 $\times$ NS61, st3 $=$ NS732 $\times$ NS15 and st4=NS27 $\times$ NS15. Standards were used to compare values of examined traits relative to certain tested progeny; they were excluded from analysis of genetic parameters. Basic plots were $8.1 \mathrm{~m}^{2}$ for each genotype in two rows, each $5.4 \mathrm{~m}$ long with $0.75 \mathrm{~m}$ distance between rows and $0.22 \mathrm{~m}$ between plants. General growing technology was applied according to agro-ecological conditions of locality.

Following traits were observed: grain yield (GY), ear length (EL), kernel row number (KRN), kernel number per row (KNR), 1000-kernel weight (1000 $\mathrm{KW})$, plant height $(\mathrm{PH})$, ear height $(\mathrm{EH})$, number of leaves above ear $(\mathrm{NL})$, and grain moisture (GM).

Analysis of variance of incomplete block design was performed according to model II (Hallauer \& Miranda 1988). Genetic correlations for yield and other agronomic traits were calculated from ratio of genetic covariance and variance (Falconer \& Mackay 1996). Randomisation of each HS group (2x20 families) was independent, so analysis excluded possibility of evaluation of phenotype variation components, because their phenotype covariance equalled genetic covariance (Bradshaw 1983).

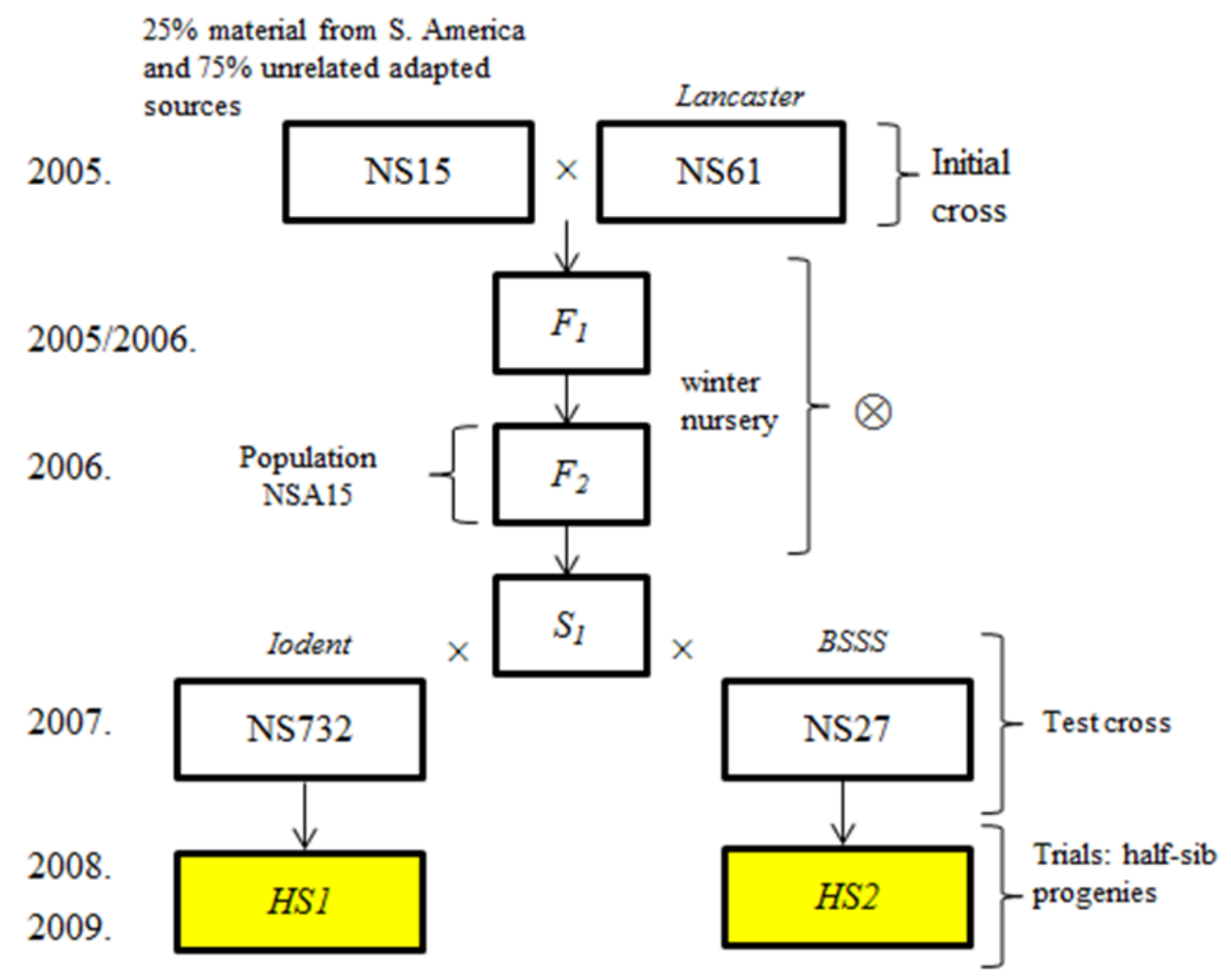

Figure 1. Obtaining of test material 


\section{Results and Discussion}

Different structure of starting population (of narrow and wide genetic base), applied selection method, effective population size, genetic drift and other factors that lead to change in allele frequency can affect genetic correlation between traits (Bohren et al. 1966, Falconer \& Mackay 1996). Genetic correlations of HS1 and HS2 among grain yield, yield components and other traits are calculated and presented with coefficients of genetic correlation in Figures 2 and 3, respectively.

Significant moderate strong negative correlation between grain yield and ear length was determined in HS1 progeny. This correlation is opposite to results of El -Lacany and Russell (1971) and Martin and Russell (1984), who determined medium and strong relations among these two traits. Although longer ears had longer cob, it was not filled with kernels fully. Ivanović (personal communication, 2012) finds that concerning yield components, none extreme value can influence positive yield increase. Therefore, genotypes with ears that were too long did not have high yield.

Yield and 1000-kernel weight were in high significant genetic correlation in both HS, with stronger correlation in HS2 regarding to HS1. Our results are in compliance with results of Husić et al. (1995) and Srećkov et al. (2007). Still, Mitrović (2014) found negative non-significant correlation coefficients among above mentioned traits. In addition, yield and kernel number per row were correlated moderate strong significant only in HS1. This is in compliance with average correlation coefficient values $(0.45)$ calculated by Hallauer et al. (2010). At the same time, relation between these traits in HS2 was negative and non-significant. Negative non-significant correlation was also found in results of Mitrović (2014).

\begin{tabular}{|c|c|c|c|c|c|c|c|c|}
\hline GY & & & & & & & & \\
\hline-0.48 & EL & & 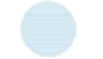 & 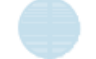 & & & & \\
\hline 0.35 & -0.04 & KRN & & & & & & \\
\hline 0.47 & 0.19 & -0.1 & KNR & & & & & \\
\hline 0.47 & 0.24 & -0.17 & 0.28 & $\begin{array}{c}1000 \\
\mathrm{KW}\end{array}$ & & & & \\
\hline 0.28 & 0.12 & -0.06 & 0.31 & 0.32 & $\mathrm{PH}$ & & & \\
\hline 0.23 & 0.12 & -0.08 & 0.05 & 0.27 & 0.64 & EH & & \\
\hline 0.32 & -0.12 & -0.02 & -0.03 & -0.01 & 0.63 & 0.4 & $\mathrm{NL}$ & \\
\hline 0.25 & -0.1 & 0.13 & 0.26 & 0.31 & 0.44 & 0.5 & 0.26 & GM \\
\hline
\end{tabular}

Figure 2. Heatmap plot of genetic correlation between observed traits in HS1 (tester NS732). Strength of genetic correlation is presented as heat scale with red colour indicating positive and blue representing negative correlations. Light colours represent lower correlations, whereas darker colours appear for stronger correlations. Abbreviations: GY-grain yield, EL-ear length, KRN-kernel row number, KNR-kernel number per row, $1000 \mathrm{KW}-1000$ kernel weight, PH-plant height, EH-ear height, NL- number of leaves above ear, GM-grain moisture. 
Low genetic correlations with yield were observed in other traits. Reasons may lay in facts that: (I) in late generations of non-breeding material recessive genes had deleterious effect in homozygous state, (II) early generations of selfing lines per se had different heterozygous levels, which was not the case in test crossing, (III) epistasis occurred. Grain yield was in positive genetic correlation to plant height and ear height in both HS. However, only amongst yield and plant height in HS2 this relation was significant. Based on 23 trials, Hallauer et al. (2010) noticed lower correlation coefficients of plant and ear height to yield. Observed correlation relationships were approximately at the same level, differing in higher yield-plant height correlation. What's more, plant and ear height were also significantly strong and moderate strong positive correlated with grain yield (El-Lakany \& Russell 1971, Betrán \& Hallauer 1996, Malik et al. 2005).
High significant correlations occurred among plant and ear height in both HS and between plant height and number of leaves. Srećkov et al. (2007) also found strongest genetic relationship for these traits. Similarly, medium correlation amongst plant and ear height was determined by Djordjevic and Ivanovic (1996).

Grain moisture was moderate strong correlated to plant and ear height. In this regard, genotypes that possess higher stalks are usually later maturing with slower moisture release. This occurs due to longer growth of vegetative parts of plant. Further on, in HS2 grain moisture was in high significant relation to 1000 kernel weight, number of leaves and in significant relation with plant height. In relation to higher average value of grain moisture and 1000-kernel weight in HS2, genotypes with lower 1000-kernel weight value release moisture faster. Additionally, grain moisture was in low and non-significant relation with other measured traits.

\begin{tabular}{|c|c|c|c|c|c|c|c|c|}
\hline GY & & & & & & & & \\
\hline 0.19 & EL & & & & & & & \\
\hline 0.12 & 0.0 & KRN & & & & & & \\
\hline-0.14 & 0.73 & 0.12 & KNR & & & & & \\
\hline 0.63 & 0.28 & -0.41 & -0.30 & $\begin{array}{c}1000 \\
\mathrm{KW}\end{array}$ & & & & \\
\hline 0.45 & 0.29 & -0.31 & 0.23 & 0.43 & $\mathrm{PH}$ & & & \\
\hline 0.37 & 0.17 & -0.39 & -0.14 & 0.49 & 0.76 & $\mathrm{EH}$ & & \\
\hline-0.03 & -0.02 & 0.05 & 0.03 & 0.08 & 0.53 & 0.40 & NL & \\
\hline-0.07 & 0.25 & -0.14 & -0.05 & 0.52 & 0.29 & 0.38 & 0.45 & GM \\
\hline
\end{tabular}

Figure 3. Heatmap plot of genetic correlations among observed traits in HS2 (tester NS27). Strength of genetic correlation is presented as heat scale with red colour indicating positive and blue representing negative correlations. Light colours represent lower correlations, whereas darker colours appear for stronger correlations. Abbreviations: GY-grain yield, EL-ear length, KRN-kernel row number, KNR-kernel number per row, 1000 KW-1000 kernel weight, PH-plant height, EH-ear height, NLnumber of leaves above ear, GM-grain moisture. 
Ear length and kernel number per row in HS2 were strong related with high significance. It implies that kernels in row were distributed on ear by length. Kernel number per row and 1000-kernel weight correlated strong, negative with high significance level, which is in line with the results of Anđelković (2000) and Mitrović (2014).

Moderate strong high significant correlations were obtained among 1000-kernel weight and plant and ear height.

Different correlations in our study indicate masking effect of desirable dominant alleles that are carried by elite line-tester (Ivanović et al. 1987). Yet, perceived correlations represent relations within observed populations. It means that due to different tester usage, different correlations can be expected.

\section{Conclusions}

To conclude, in most cases correlation levels of HS1 and HS2 differed significantly. Sometimes they even had opposite signs (e.g. yield-ear length relation). Yield and 1000 kernel weight were highly correlated in both HS. Plant height was in positive correlation relationship with ear height and number of leaves in HS1 and HS2. Observed differences in strength and sign of correlation imply on significant influence of tester in each group of HS progeny. Also, there was specific interaction among alleles from NSA15 and tester's alleles, whether there was inter-, or intra-locus interaction. Finally, our results gave insight in genetic potential of NSA15 population with narrow genetic base.

\section{References}

Alvi, M. B., Rafique, M., Tariq, M. S., Hussain, A., Mahmood, T., \& Sarwar, M. (2003). Character association and path coefficient analysis of grain yield and yield components maize (Zea mays L.). Pak. J. Biol. Sci., 6, 136-138.
Andelković, V. (2000). Identification of maize (Zea mays L.) resistance indices to drought in progeny with exotic germplasm (in Serbian). Doctoral dissertation, University of Novi Sad, Faculty of Agriculture.

Betrán, F. J. \& Hallauer, A. R. (1996). Characterization of interpopulation genetic variability in three hybrid maize populations, J. Hered., 27, 319-328.

Bohren, B. B., Hill, W. G. \& Robertson, A. (1966). Some observation on asymmetrical correlated response to selection. Genet. Res. (Camb)., 7, $44-57$.

Bradshaw, J. E. (1983). Estimating the predicted response to S1family selection. Hered., 51, 415-418.

Cochran, W. G. \& Cox, M. G. (1957). Experimental designs. 2nd ed. John Wiley and Sons, Inc., New York.

Djordjevic, J. S. \& Ivanovic, M. R. (1996). Genetic analysis for stalk lodging resistance in narrow-base maize synthetic population ZPS14. Crop Sci., 36, 909-913.

El-Lakany, M. A. \& Russel, A. W. (1971). Relationship of Maize Characters with Yield in Testcrosses of Inbreds at Different Plant Densities. Crop Sci., 11(5), 698-701.

Falconer, D. S. \& Mackay, T. F. C. (1996). Introduction to Quantitative Genetics. 4th edition. Addison Wesley Longman, Harlow, Essex, $\mathrm{UK}$.

Hallauer, A. R. \& Miranda, J. B. (1988). Quantitative Genetics in Maize Breeding. 2nd ed. Iowa State University Press. Ames, IA.

Hallauer, A. R., Miranda F. J. B. \& Carena, M. J. (2010). Quantitative genetics in maize breeding. Springer, New York, pp. 663.

Husić I., Kojić, L., Ivanović, M. \& Stojnić, O. (1995). Genetic and phenotypic correlations between grain yield and yield components for $\mathrm{S}_{1}$ and $\mathrm{HS}$ progenies in two early maturity synthetic populations of maize. Genetika, 27(2), 93-101.

Ivanović, M., Stojnić, O. \& Greder, R. R. (1987). Correlations among grain yields of full-sib, half-sib, and selfed progenies in broad and narrow base population of maize (Zea mays L). Genetika, 19(1), 3745.

Malik, H. N., Malik, S. I., Hussain, M., Chughtai, S. U. R. \& Javed H. I. (2005). Genetic correlation among various quantitative characters in maize (Zea mays L.) hybrids. J. Agri. Soc. Sci., 1(3), 262-265.

Martin, M. J. \& Russel, A. W. (1984). Correlation response of yield and other agronomic traits to recurrent selection for stalk quality in maize synthetics. Crop Sci., 24, 746-50.

Mitrović, B. (2014). Genetic variability and multivariate analysis of important agronomic traits in maize population with narrow genetic basis (in Serbian). Doctoral dissertation, University of Belgrade, Faculty of Agriculture.

Rissi, R. \& Hallauer, A. R. (1991). Evaluation of four testers for evaluation maize (Zea mays L.) lines in a hybrid development program. Rev. Bras. Genet., 14, 467-481.

Srećkov, Z., Boćanski, J. \& Ivanović, M. (2007). Genetic and phenotypic correlations between oil content and morphological traits in high oil maize population NSU1. Genetika, 39(2), 103-112.

\section{Uticaj različitih testera na genetičke korelacije u populaciji kukuruza uske genetičke osnove NSA15}

\section{Dušan Stanisavljević · Dragana Rajković · Bojan Mitrović · Miroslav Zorić · Petar Čanak · Filip Franeta $\cdot$ Milan Mirosavljević}

Sažetak: Cilj ovog istraživanja je bilo određivanje korelacija između prinosa zrna i drugih morfoloških i agronomskih osobina dve polusrodničke grupe potomstava (HS) kukuruza. Nasumično odabrane biljke iz svake $\mathrm{S}_{1}$ familije su ukrštene sa testerima NS732 i NS27. Dve polusrodničke grupe potomstava su formirane tako da je svaka $S_{1}$ familija ukrštena sa oba testera. Poljski ogledi sa nepotpunim blok dizajnom sa tri ponavljanja po setu su posejana 2008. i 2009. na četiri lokaliteta. Praćene su sledeće osobine: prinos zrna, dužina klipa, broj redova zrna, broj zrna po redu, masa 1000 zrna, visina biljke, visina klipa, broj listova iznad klipa i vlaga zrna. Kod HS1 potomstva je uočena srednje jaka negativna korelacija između prinosa zrna i dužine klipa. Takođe, visina biljke i visina klipa su bile u jakoj vezi kod oba HS potomstva. Dobijene razlike u stepenu korelacije ukazuju na značajan uticaj testera u svakoj grupi HS potomstava. Ključne reči: genetičke korelacije, klip, korelacije, kukuruz, polusrodničke grupe potomstva, prinos zrna, visina 